Article

\title{
Symbols and Function of the Zhang Clan Han Army Sacrificial Rite ${ }^{+}$
}

\author{
Shuyun Guo \\ Institute of Shamanic Culture, Dalian Minzu University, Dalian 116600, China; guoshuyun@163.com \\ + Translated by Liang Yanjun; Institute of Translation Studies on Ethnic Groups, Dalian Minzu University, \\ Dalian 116600, China; liangyanjun_88@163.com
}

Received: 6 December 2018; Accepted: 21 January 2019; Published: 1 February 2019

\begin{abstract}
The Eight Banners System is the social organizational structure of the bannerman (qiren, 旗人) from the Qing dynasty and the fundamental system of the country under Qing rule. It is divided into three types: the Manchu Eight Banners, Mongolian Eight Banners, and Han Army Eight Banners. The Han Army was a special group in the Qing dynasty between the bannerman and the commoners (minren, 民人). The sacrificial rite of the Han Army is a form of comprehensive shamanic ritual based on the traditional ancestor worship of the Han people. However, it is influenced, to some extent, by the shamanic ritual of the Manchus involving trance-dance. It finally took shape as a unique sacrificial form different from both the Manchu shamanic rite and the traditional ancestor worship of the Han minren. As a special system of symbolic rituals, the Han qiren's sacrificial form embodies shamanic concepts and serves two functions: (1) dispelling evil and bringing in good fortune for the community; and (2) unifying the Han bannermen's clans and strengthening the culture, identity, and tradition of the Han people, who were living under Manchu rule during the Qing dynasty.
\end{abstract}

Keywords: Han Army; shamanism; Eight Banners System; wula; Manchu; bannerman

Rites have a close correlation with symbols. A rite itself is a symbolic system that embodies rich internal and external meanings. As has been said, "Every rite is symbolic, and this gives rise to the rite's creativity. In turn, ritual and symbolic functions are closely related with each other" (Peng 2007, p. 202). A shamanic rite is a specific system of symbols consisting of a series of given signs which reflects the sacred aura of shamanistic cultures. These symbols in shamanism bear similarity, while maintaining their own peculiarity. An ethnic group or national identity is one of the basic characteristics of a symbol. The ritual coherence of a group relies on the fact that most of the symbols of particular rituals reflect the values, orientations, and psychological states of that group, and the symbols used by different groups often have their own emblematic qualities and explanations. This is particularly evident in the cultural system of shamanism. Shamanism is a kind of original religious form based on clan structures, whose ritual symbolic system is characterized by regional characteristics. Generally speaking, although there are some symbols in shamanic rites that can be commonly recognized by all shamans, there also are some symbols that are unique to particular clans or ethnic groups, thus presenting the richness and diversity of the symbolic system of shamanic rituals. The Han Army rite uses some commonplace shamanic symbols. For example, the Shengan (神杆, sacred pole) ${ }^{1}$ symbolizes the connection between the three realms (sanjie) and the ritual drum represents a vehicle moving from one realm to another.

1 Shengan (神杆, sacred pole): newly cut tree pole used in Manchu sacrificial rites worshipping gods as a symbol of contact with the spirit-realm above. 
Scholars have given dramatic analyses of the Han Army² or bannermen's sacrificial rite (Kister 2010, pp. 70-81; Ren and Sun 1998), but there is no agreement among them about the cultural aspects of its dramatic form and structure. Based on the study of the model of the three realms of the universe, the manner in which the shenjiang (神匠, officiating shaman) makes contact with the god realm, and the kinship organization related to the shamanic rituals, it was seen that there was a great similarity between the Han bannermen's rite and the traditional Manchu shamanic rite of ancestor worship and trance-dance. By virtue of this, the former differed greatly from the everyday rituals of both Manchu and Han commoners. In addition, folk activities, intercultural communication, and the merging of the Manchu and Han peoples have helped shape the nature of the rites since the historical integration of the two peoples in the Qing dynasty. Hence, there is a homogeneity of symbols between the Han bannermen's rite and the traditional rite of the Manchu shamans. This resulted in the Han bannermen being absorbed into the Manchu identity without being ethnically Manchu.

The Han Army, or Hanjun, is a special group of Han Bannermen (qiren旗人) ${ }^{3}$, who defected from the Ming army and formed the main part of the Eight Banners ${ }^{4}$ system in the Qing dynasty. These Han soldiers and their families, who lived in garrisons, were distinguished, by classification, from Han civilians or minren ${ }^{5}$ and formed a hereditary and occupational caste in the longevity of the Eight Banners. These Han people were enrolled by the Manchus in this new organization during the late Ming (1639-1642) and before the Battle of the Shanhai Pass in 1644. It was in 1642 that the "Han Army of Eight Banners" (hanjun baqi 漢軍八旗) was established on the basis of an earlier banner system and went on to have a unique place in Chinese history, in that, apart from their military role and function, the Han bannermen maintained an important cultural balance between the Manchu and the Han peoples (Sun 2006, p. 52), which had the objective effect of consolidating Qing rule. Hence the Qing saying, “No distinction between Manchu and Han, but between bannermen and civilians" (不分满汉， 但问旗民).

The Han Army is composed of the Old Han Army and the New Han Army. The former refers to persons who joined the army in the late Ming and early Qing dynasties, and the latter to those who joined after Manchu victory in the Battle of the Shanhai Pass and significantly increased the numbers of the Han bannermen. After 1750, however, many Han bannermen were forced to transfer to the Green Standard armies or to become commoners, in order to make room for Manchus on the banner rolls (Crossley 1989, p. 92). The two groups lived through different experiences after the demise of the Qing dynasty. The Eight Banner system facilitated integration of the Han and Manchu peoples when a clear boundary between the two had always existed before the Republican era. As has been said, "There is a tendency of assimilation in their life, economy and customs" (Wang 1990, p. 36). In the past few years, I have investigated the sacrificial rites of the Han Army by means of observation and interview. I participated in the Zhang clan sacrificial rites during fieldwork in 2012, observing and recording every detail of the rite on the spot. In addition, I visited Mr. Zhang Rongbo and Mr. Zhang Zonghua, the inheritors of shamanic traditions within the Zhang clan, several times in order to understand the symbolic meaning and connotations of the rites. The following is a case study on the Old Han Army rites as performed by the Zhang clan in Wula (乌拉), Jilin Province, with a focus on their ideology and fundamental characteristics.

2 Han Army: abbreviation of Han Army Eight Banner. See Han Army Eight Banners.

3 Qiren (旗人): (Bannermen) people who joined the Eight Banners in the Qing dynasty, as distinguished from commoners (minren).

4 Eight Banners: military and political system of the Qing dynasty, established by Nurhaci in 1601: Yellow Banner, White Banner, Red Banner, Blue Banner, Bordered Yellow Banner, Bordered White Banner, Bordered Red Banner, and Bordered Blue Banner, comprised of Manchu Eight Banners, Han Army Eight Banners and Mongolian Eight Banners, they later formed the military backbone of the Qing dynasty.

5 Minren (民人, commoners) are Han people that lived in the northeast of China during the Qing dynasty, as distinguished from bannermen (qiren 旗人). 


\section{The Han Army Zhang Clan}

The Zhang clan settled in Gongtong village, Wulajie Township Jilin province. Gongtong village was located $1 \mathrm{~km}$ west of Wula during the early years of the Qing dynasty. It was originally an alluvial island running from south to north in the Songhua (Sungari) River like a huge gourd, wide at the south and narrow at the north. In the first year (1644) of the Qing Shunzhi顺治 period, a Manchu family with the surname Qian settled in Gongtong and lived mainly through fishing, hunting, and farming.

The erection of wooden houses on the high mounds earned the village the name "Gouluotu," which means "mound" in the Manchu language and which is transliterated as Gongtong in Chinese. During the 360 years since their settlement in Gongtong, the Zhang clan went through separation and reunion many times. After eighteen generations, it is now a large clan of nearly 4000 members, with seven generations living together. According to genealogical records, the clan originated in Laiyang, Dengzhou, Shandong. The earliest ancestor was Zhang Deyao, who came to the Liaodong Peninsula alone by boat and made a lot of money by digging ginseng in the virgin forest of the hinterland of Changbai Mountain. Later, he returned home and moved with his wife and two younger sons, Jinghe and Jingfa, to Mukden (present-day Shenyang). He took part in a military campaign launched by the Qing, defeating the Ming troops led by the Commander of Liaodong Region, thus "making great contributions." ${ }^{\prime 6}$ Jingfa and his son returned to Mukden and reported their duties to the feudal court. They respectively acted as “Third-Class Imperial Guard (三等侍卫) ${ }^{7}$ " and “Chief Superintendent for the Three Storehouses (三库总达) ${ }^{8 \prime}$. Jingfa's son, Dengke, was a craftsman who made bows for the Manchu royalty and thus joined the Bordered Yellow Banner (镶黄旗) of the Han Army Eight Banners 9 . In the 8th Year of the Shunzhi period (1652), Dengke "along with his five sons upon the imperial edict moved" from Mukden to the ancient Wula City, where he "made bows and arrows for the defense of the frontier." Then, he settled in Gongtong Village as a bow-maker under the Zongguan Yamen of Dasheng Wula (打牲乌拉总管衙门). ${ }^{10}$ Thanks to his unique bow-making, the court added the character “jiang (匠)," which means craftsman, between Gong and Tong in the village name. This three-character name had been used throughout the Qing dynasty, but with the coming of the Republic in 1949, it reverted back to the original name Gongtong.

Following the settlement in Gongtong, the Zhang clan witnessed the departure of three brothers, Zhang Yunpeng, Zhang Yunlong, and Zhang Yunfeng, during the reign of the Qianlong period. They went to Jiutaizhan (九台站) ${ }^{11}$, where they "cleared the land and established another property." The fourth brother "returned home alone to serve the Brigade Yamen (协领衙门);"12 Zhang Yun'e, the fifth brother, "looked after the ancestral graveyard and paid homage to the deceased" in the hometown.

Both the genealogy and ancestral graveyard in Gongtong village have long served as the center of the Zhang clan. The village now has 412 households: 70 Manchu households, 166 of the Han Army, 170 Han, 2 Hui, and 4 Mongol. Apart from the Zhang clan, four other Manchu clans settled in the area very early: Qian, Wang, $\mathrm{Fu}$, and Zhao. The riverside villagers who live in the nearby ancient city of Wula have multiple means of livelihood. During the Qing dynasty, many caught kaluga (beluga) sturgeon, gathered freshwater pearls, and offered the sturgeon to the imperial court. In the late Qing period, Gongtong was a transit station between Jilin and Harbin, as well as a distribution center for

6 The facts of the Zhang family in this article are taken from "Zhang family Genealogy Introduction", which is an unpublished manuscript.

7 Third-Class Imperial Guard (sandengshiwei三等侍卫): three levels of Qing courtguards, ranked according to the importance of the work for which they are responsible.

8 Three Storehouses: institution of Qing dynasty for supervising cloth, pigments, and capital funds.

9 Han Army Eight Banners: social organization of Han peoples of those who joined in the Qing dynasty, based on the Manchu Eight Banners.

10 Zongguan Yamen of Dasheng Wula (打牲乌拉总管衙门): Qing government agency in Wula, Jilin, responsible for the administration of clans in their offering of honey, ginseng, pearl, and other specialty items of the region to the palace.

11 Jiutaizhan (九台站): ancient posthouse for court or military couriers.

12 It is a local agency responsible for administrative affairs established in the Qing dynasty. 
Wula merchants and foreigners. Seven or eight families with large or small boats were engaged in water transport. That of the Seventh Master Zhang was famous on the Harbin-Jilin route, and astounding stories about it are still fresh in elders' memories and circulate among the local people. Since modern times, Gongtong villagers have mainly worked in farming. The village now owns 312 shang垧, (around one hectare). In early times, the crops were mainly wheat and soy beans, with corn, sorghum, and vetches in waterlogged areas. After 1949, especially during the period when the land was worked by communes, high-yield corn was the main crop. With land management and agricultural production coming under peasants' semi-private control during the Reform and Opening-up (改革开放) economic campaign that started in 1978, villagers began planting more economically productive crops, such as vegetables, to multiply their incomes. In recent years, young people have left the farmland for work in the cities, leaving just the middle-aged and elderly, along with students of primary and secondary school age, to live in Gongtong.

\section{The Han Banner Sacrificial Rite}

The Han Army sacrificial rite, called Shaoxiang (烧香) ${ }^{13}$, involves worship of the ancestral gods of a clan, such as the Zhangs, under the influence of the Manchu shamanic trance-dance (worshipping gods in the form of singing and dancing is commonly known as trance-dance in Manchu folkway). While still based on the sacrificial customs of the Zhang clan and the aforementioned Manchu shamanism, the final form of the ritual differs from both. The officiant is called shenjiang (圣匠, sacred craftsman) or chama (察玛). The rite has a unique symbolic system with eye-catching features. It is conducted by the Zhang clan in the long (龙, dragon) year ${ }^{14}$ to "foster the prosperity of the whole clan." At the end of the Qing dynasty, the mukunda (穆坤达, chieftain) ${ }^{15}$ Zhang Ruichen advised that the time of the official sacrificial rite should be changed to the shu (鼠, mouse) year because this small animal has astonishing reproductive powers. When the 2012 long year came around, however, the new chieftain, Zhang Xinhua, along with an important transmitter of the shamanic culture Zhang Rongbo, suggested that, now that their clan was a large one, they should use the long year again. The clan agreed, with the aim of better preserving its shamanic ritual tradition.

From 29 February to 2 March 2012, the Zhang clan held a three-day rite at Gongtong village called Shaoguanxiang (烧官香). ${ }^{16}$ Its symbolic system and sacred world are made up of a number of sub-rites, which are explained below.

\section{First Day of the Rite: Anzuori (安坐日, Placement Day)}

Lingsheng (领牲) is the pre-requisite step of verifying the gods' acceptance of the sacrificed animal. In the Han Army rite, the sacrificial offering is usually a pure black boar. The shamans bring it to the shrine to an accompaniment of drumbeats and then set it on the ground with its head facing south. The officiant leads all the clansmen in kneeling down and muttering words in prayer, asking for acceptance of the sacrifice. Then, he pours drops of liquor into the boar's ear. If the ear stirs, this signifies that the ancestral gods have accepted the offering; and everyone congratulates one another. If the ear does not stir, it means that the gods have rejected the sacrifice. In that case, the chief shaman or family head checks to see if something may have offended the ancestral gods. If it is identified, the mistake is immediately corrected, and the procedure of pouring liquor into the boar's ear is repeated. If the procedure goes smoothly this time, that is taken as a sign of the success of the sacrifice It has a positive effect on the general atmosphere and the mood of the participants of the rite. Liaogua (料卦, divination): liao (料) here means "prediction" or "foretelling," and gua (卦) is a general term for divination tools, in

13 Shaoxiang (烧香): traditional Manchu and Han Army sacrificial clan rite.

14 Long year (Dragon year): one of the twelve zodiac signs of the Chinese lunar calendar. See Chinese Zodiac.

15 Mukunda: Means "chieftain" in Manchu. Mukun means "clan," and da means "chief."

16 Shaoguanxiang (烧官香): name of Manchu and Han Army sacrificial clan rite as held every twelve years. 
this case usually a deer chest bone or boar tusk. In the Chang clan ritual, the chief shaman makes five divinations about the good or bad results of the main stages of the rite. The chief shaman kneels on one knee, raises the gua with both hands, and then places it on a drumhead. The drum is then turned upside down to let the gua slip down to the ground to conclude the divination.

Linganzi (领案子, welcoming the gods): The Han Army rite is held every twelve years. Several days before it begins, portraits of gods are taken down from the shrine and burned, and $24 p u$ (铺) ${ }^{17}$ of new portrayals are carefully painted and stored in a clean place in the courtyard. On the first day, the family head carries the portraits on his back and enters the main hall of the house, preceded by an assistant intoning the following chants:

With birch bow in the left arm and diaolingbaojian (雕领宝箭, eagle feather arrows) in a vessel, the bearer holds two sticks of incense at his bosom and a pair of precious vases in his hands. Amid lanterns and torches, two steel swords come into sight. Then a pair of banners open the road, followed by the banners to welcome the gods. In front of the entrance door of the house, loud drumbeats and fluttering banners greet the ancestors. ${ }^{18}$

With the divine portraits brought in, this part of the rite comes to an end.

Songjian (送箭, shooting arrows): After greeting the gods and spirits of the deceased, a shaman shoots three eagle feather arrows in succession above the entrance door to expel foreign spirits and evil ghosts. Otherwise, they could spoil the whole atmosphere.

\section{Anzuo (安座, Placement): 24 Portraits of the Ancestral Gods Are Placed at the Shrine in Strict Order}

Hufawuling (护法五铃, five guardian rings): The chief shaman hangs bronze rings, each tied with cloths of five colors (green, yellow, white, blue, and red), at the side of the shrine and over the portraits in accordance with strict clan regulations. According to shamanic thought, the tinkling of bells produces a fearful sound that can drive away demons and evil spirits.

Canshen 参神 (参神, worship of the gods): Having cleansed their hands and faces, all the shamans, in ritual robes, beat their drums and burn incense under the leadership of the chief shaman. During the drum-beating, they walk in a squatting manner and gang step (罡步) ${ }^{19}$ as a sign of utmost veneration.

Lanmen (拦门, blocking the gateway): To keep evil spirits out of the house during the rite, the shaman tramps on the threshold and then shouts out an incantation to block the gate. In the course of the whole sacrificial rite, there are six such gate-blocking procedures.

Qishen (起神, ritual preparation): Wearing a waist ring and a sacred hat, the chief shaman sings nicely before the shrine a chant to raise the gods' spirits and put them at ease. Then, two assisting shamans beat their drums, and all the shamans join the soothing chant and let the gods enjoy the incense. All this is a way of offering prayers for good health and happiness of the host family, old and young, as well as their many livestock.

Dawulu打五路 (打五路, opening the five paths): A shaman wields a large rice-chopper blade and points it in the five cosmic directions (east, south, west, north, and center) to summon the kaishanwanzi (开山王子, Mountain-chopping Prince), who possesses him and allows him to show the god's matchless power to scare away all demons and evil, inauspicious, and unclean beings so that all the gods can safely arrive and enjoy the worship.

$17 p u$ : Han Army unit of measurement of gods.

18 All the chants quotes in this paper are from, Divine Book of The Han Army Zhang Cclan, unpublished, a shamanic manuscript covering the rules and steps of the Zhang cClan version of the Han Army sacrificial rite.

19 gang step: step gesture, ritual duck walking to show respect for a god according to Scripture from the River Luo. 


\section{Second Day of the Rite}

Kaijinkou (开金口, consecration): A shaman paints the mouths of the gods red to symbolize their ritual consecration and presence. The chief shaman makes gestures of washing and combing the ancestors and deceased in steps that have rich meaning. First, the shaman gets three drops of blood from the crest of a rooster and sprinkles them on the portraits of the gods to indicate that they are consecrated and so have power to drive away evil spirits. Then, the chief shaman uses a stalk of sorghum to hold up a mirror and comb the divine portraits with seven silver needles as a gesture of grooming them. He then scatters grains of rice, soybeans, and corn toward the shrine and in the house and sprinkles liquor three times. All these symbolic actions serve to recall the ancestors' kindness and show filial duty by washing their faces and combing their hair. Fangshangwushen ${ }^{20}$ (放晌午神, show of the gods at noon): In this most important step in the Han Army rite, the shamans invite the gods at noontime, chanting, renewing the burning of the incense, and entering the sacred hall to the rhythmic beat of drumming. One after another, the shamans then greet them with dramatic presence, and send off each god. Fangshangwushenis is the most wonderful ritual in the whole event. It bolsters faith, while at the same time serving as entertainment for the clansmen and the gods themselves. Fangshangwushen takes place in the following eight stages:

(1) Fang Xianfeng (放先锋, show of the Vanguard Warrior) ${ }^{21}$ : This is an archetypal brave warrior by the name of Xue Rengui (薛仁贵) (614-643), a great Tang dynasty general who devoted himself to his military career. A shaman mimics preparations for his expedition in a ritual dance, guiding his horse with a whip, cleaning it with a brush, saddling it, tying on the waist-belt, mounting it, and shooting three arrows. The display aims to foster in the clansmen a sense of national loyalty and courage to fight against enemies. (2) Fang Taiwei (放太尉, show of the Boar Spirit): The Boar Spirit Taiwei has a green head and face, with a pair of long, tusk-like needles sticking out of his mouth. Possessed by this god, a shaman mimics his birth in Nanjing and his growth in the Drum Tower (鼓), ${ }^{22}$ in the Gulou district of the city. He runs to the altar and enjoys the offerings. He then goes outside to play and does not want to come back to the sacred clan hall, so the chief shaman has to get him back in by beating the sacred drum.

(3) Fang Fengdu (放丰都show of Fengdu): Fengdu refers to hell or the netherworld. A shaman puts one end of a two-meter noose of white cloth around his neck, and the other end around his left leg. Another shaman then inserts chopsticks into the noose, pulls on it, and twists it with all his strength. The possessed shaman struggles in the vigorous twisting of the noose, displaying the heartbreak of the Buddha's disciple Mu Jianlian (目胖连), who saw his mother subjected to severe torture in the netherworld.

(4) Fang Xintongwangzi (放心痛王子, show of the heartbroken prince's feelings): Li Shimin (李世 民) (598-649), who became Tang Emperor Taizong (太宗), was benevolent towards his countrymen and open-minded to new ideas. The shaman mimics the preparation of the emperor's chariot and the help given to him as he boards it. He then clutches his chest and moves back and forth on the ground as a show of Li Shimin's great grief and love of his men upon seeing his generals and soldiers drowning in a river.

(5) Fang Yingshen (放鹰神, show of the Eagle Spirit): A shaman holds a piece of raw meat to attract and tease the "yellow eagle" regarded as shengying (圣鹰, sacred eagle), who is portrayed by another shaman possessed by the Eagle Spirit. The possessed shaman dances around, imitating an eagle's actions, snatching and eating meat, fluttering, and spreading wings. This set of dances lets the majestic eagle come alive.

20 Fangshangwushen: Fang, meaning "put in place," "release," "let oneself go," and sometimes "imitate," refers to the behavior of the possessed shaman: possessed by the Eagle God, he acts like an eagle; by the Snake God, he acts like a snake.

21 Referring to Xue Rengui, great general of the Tang dynasty. See Fangxianfeng.

22 Drum Tower: 1382 Nanjing Qing dynasty structure of 9100 square meters for imperial and other celebrations needing the drum accompaniment. 
Daoyuping (倒宝瓶, emptying the jade vases) Aimed at easing the participants in the Han Army rite, this is a ritual symbolizing the resolution of conflicts between father and son and among brothers. On the first day of the rite, the host holds a vase covered with red paper and filled with sorghum, symbolizing that all will be well. Another clansman holds a similarly covered vase filled with silver, standing for wealth. The vases are then emptied as a sign that family conflicts will be eased and good fortune will visit the clansmen. The accompanying chant states: "Fathers and sons are of the same blood, and brotherly ties are strong. Forget your complaints, and they will all melt away as the snow melts in the sunshine. Let the gods be our witnesses!" After the chant, a shaman tears off the red sheet of paper from the vases and pours out the sorghum and silver-pieces while the drumbeat echoes through the air. The two men who emptied the vases join hands and hug each other, and steeped in an enthusiastic and harmonious mood, everyone bursts into applause and cheers.

Fenqixiang (焚旗像, burning the banner effigies): Paper effigies are necessary magical implements. At the clan's shamanic rites, shamans set up two colorful, human-shaped effigies made of paper, one for the gods and the other for ghosts, as the seats where the gods and ghosts dwell. Identical in form and structure, each consists of a head and clothed body. However, the effigy of the god is taller by three cun (寸, Chinese unit of length), or about 10 centimeters, meaning they have more power. At the end of the rite, the effigies are brought to the eastern courtyard and burned, to the accompaniment of shamans' endless drumming and a chant stating, "With our burning of the effigies in the courtyard, the gods depart with our burning of the effigies in the courtyard, the gods depart".

Fangwudaonianban ${ }^{23}$ (放五道撵班, show of the god driving away ghosts): Both the gods and ghosts manifest their supernatural powers during the sacrificial ritual. Now, in a show of battle between them, malicious ghosts, enacted by assistant shamans screaming terribly, demand the same treatment and offerings as the gods. After a fierce competition, the defeated ghosts finally leave and the burning of the effigies ends the rite.

\section{Third Day of the Rite}

Guaxiliu (挂喜絈, hanging the skein of happiness): At maoshi (卯时) (between 5 and 7 a.m.), the shamans and clansmen together hang up the "skein of happiness," a long rope woven from short strips of newly dried grass. They tie five rings of red strands around the skein and hang it from the lintel of the house of the family holding the sacrifice, to tell all in the neighborhood that the rite of ancestral worship has now ended. Persons born in the year of qingniu (青牛, green ox) or baima (白马， white horse) according to the Chinese zodiac, ${ }^{24}$ as well as those in mourning, should not enter; for they could offend the new gods and make them bring bad luck or disaster upon the family. The skein of happiness remains hanging from the lintel for one month. It is then taken off and sent to a clean place. With that, the three-day sacrificial rite comes to a conclusion.

\section{Sacred Symbols of the Han Army Rite}

As Victor Turner points out in his study on the relation between ritual and symbol, "One aspect of the process of ritual symbolization among the Ndembus is, therefore, to make visible, audible, and tangible beliefs, ideas, values, sentiments, and psychological dispositions that cannot directly be perceived. Associated with this process of revealing the unknown, invisible, or the hidden is the process of making public what is private or making social what is personal. Anything that cannot be shown to be in conformity with the norms or in terms of the values of Nedembu society is potentially dangerous to its cohesion and continuity" (Turner 1967, pp. 49-50). The Han Army rite constitutes a unique symbolic system embodying the group's cognitive orientation on nature and society. The

23 Fangwudaonianban: wudao, Daoist god governing the birth and death; nianban, expelling the ghosts, Nian meaning "expel" in Chinese, ban referring "ghost" in the Han Army sacrificial rite. See Wudao Nianban.

24 Chinese Zodiac: animal signs based on a twelve year cycle and calculated by the Chinese lunar calendar: rat, ox, tiger, rabbit, dragon, snake, horse, sheep, monkey, rooster, dog, and pig. 
rich meaning of its sacred symbols gives life to the Han Army sacrificial rite as a religious system that includes nine categories: nature gods, animal spirits, heroic ancestral gods, folk gods, Han Army shamanic ancestor gods, celestial gods, Buddhist gods, Taoist gods, and various spirits. The rite gives new expression to elements absorbed from older Manchu shamanic rites, such as: Fangshen (god shows), Lingshen (acceptance of the sacrificial animal), and Guaxiluo (hanging the skein of happiness). The result is a distinct set of ritual forms that exists only in the shamanism of north China.

In its new form, the Han Army rite imparts cultural originality to those features readily found in traditional shamanic cultures, which preserves peoples' religious belief with greater independence and stability than in other religious ideologies and beliefs. Not only are the basic beliefs, ritual forms, and myths inherited from generation to generation, but effigies of the gods and spirits, musical instruments, ritual dress, and plastic arts give expression to the beliefs through particular procedures that, once shaped, are passed down with typical traditional characteristics and little variation: "The preservation of these mythic names, the long life of these fables, and their satisfying the religious, poetical, and moral wants of succeeding generations, though strange and instructive, is not the real difficulty" (Müller 1909, p. 20).

The rite's evolution and development through centuries among clans has always abided by the ritual tradition and striven to maintain the original patterns and procedures, with the political movements and changes of modern society having little impact on it. As performed by the Han Army Zhang clan at Wula, the rite gives evidence that once ritual symbols are accepted by clansmen, they retain their stability and vitality. As Clifford Geertz once said, "It is a cluster of sacred symbols, woven into some sort of ordered whole, which makes up a religious system" (Geertz 1973, p. 129). In the Han Army rite, there are many symbols and symbolic media in the form of material objects, ritual actions, and language, which are combined to constitute a religious system rich in sacred meanings. First and foremost, symbols evoke mythic meanings involving gods and ghosts. Throughout the entire ritual, the world of gods and ghosts, which the clan firmly believes in, is manifest through the symbols. The banner effigies, for example, are important, unique symbols in the Han Army shamanic rituals. As mentioned above, with one being taller than the other, they respectively represent the gods and ghosts along with the temporary abodes that constrain them from moving about.

As a main part of the symbolic systems of shamanism, the 24 gods worshipped in the Wula rite are a generic term for all the gods worshipped by the clan. Their symbolic embodiment in the shen'an (神案, divine portrayals) is worshipped by the clansmen for the blessing of family members, and the deities they represent range from nature gods and animal spirits to ancestral gods. Examples of the gods are the Tiger Spirit, ${ }^{25}$ Shangshen $^{26}$ (上神, Supreme God), Banner Deity, Vanguard Warrior, (关爷), Fengdu, Zhushen Taiwei (猪神太尉, Boar Supreme Commander), Yanguang Niangniang (眼光娘娘, Goddess of Eyesight). On the ghost side, there are also the撵班 (nianban, bands of ghosts). illness; chouchang (抽肠, disembowelling ghosts), choujin (抽筋, jerking out tendons), touteng (头疼, headache), kelao (咳 唠, terrible coughing), and mihu (迷糊, mental confusion). In the Han Army rite, therefore, shamanic symbols involving the gods and ghosts make up the Han Army form as an effectively integrated system. Although based on the original shamanic beliefs and the divine characters of the gods, the Han Army rite is nevertheless embodied with newly introduced properties that have the dual function of inviting propitiousness and dispelling misfortune. Symbolic characteristics of the gods and ghosts are reflected in the shaman's robes, ritual utensils, and chants, which contribute to the system of comprehensive symbols. The "god shows" give expression to the supernatural powers, skills, and specific nature of each of the gods that possess the shamans who perform the shows with their ritual assistants. The Chinese character fang (放) here suggests the meaning of "show" or "performance," which forms an important element of shamanic ritual. The show of the Eagle Spirit mentioned above displays the

25 Animal god worshipped by the ethnic groups of northeast China.

26 Supreme God: Han Army Sky God. 
god's supernatural powers and characteristics through their movements and stage instruments. In the show of the god driving away ghosts towards the end of the Han Army rite, the use of masks enables shamans and their assistants to complete the transformation from human to ghost. Sacred space and time are marked off symbolically by the procedure of ensconcing the gods on the first day of the rite and hanging the skein of happiness on the last day, which marks the beginning and the end of the rite, respectively. Left to hang for a whole month, the skein symbolically embodies an extension of the sacred space-time of the rite. All people, no matter what their psychological makeup might be, have an urge to see good fortune and happiness, and they do so in varying ways. As a means of expelling evil and ushering in good fortune, the Han Army rite turns to material objects and specific procedures to symbolically embody this urge. For example, the ritual of shooting three arrows in the show of the Vanguard Warrior aims at driving away evil and guaranteeing safety by shooting three eagle arrows toward the entrance door sill. Other aspects of the rituals of hanging the skein of happiness in guaxiliu and the consecration of divine portraits in kaijinkou all reflect wishes for good fortune. The pouring out of sorghum and silver pieces from the vases in daoyuping serves symbolically to put the participants at ease. All such symbolic actions elevate the mental state of clansmen and boosts their confidence in life when suffering a reverse of fortune.

As the theologian John Herman Randall says, "What is important to recognize is that religious symbols belong with social and artistic symbols, in the group of symbols that are both nonrepresentative and noncognitive. Such noncognitive symbols can be said to symbolize not some external thing that can be indicated apart from their operation, but rather what they themselves do, their peculiar functions" (Randall 1958, p. 114). It is a widely accepted notion that symbols are capable of strengthening clan cohesion. Symbols serve to embody a group's values for the maintenance of group stability and symbols that provide the foundation for religious activity are social products that provide social structure. This function not only existed in prehistoric society, but also exists in modern society.

Shamanic sacrificial ritual helps strengthen the collective identity of a group. As Wolfgang G. Jilek says of shamanic rites, "The annual Spirit Dance ceremonial provides the participant with support, protection, acceptance and stimulation. Group solidarity is stressed in speeches held during ceremonial gatherings. Perhaps the most relevant group therapeutic aspect of the ceremonial is that participants are turned from egocentric preoccupations to collective concerns and the pursuit of collective goals" (Jilek 1992, p. 91). In the warm-hearted mood of a clan ritual, the communal expression of the mental realm of the clan's culture strengthens clan harmony through the sharing of mutual emotions in the presence of the visiting ancestral gods and in admitting their oracles to the group. The emotional appeal of the ecstasy of the possessed brought about by the shaman's own possession by the gods played an expansive, catalytic role in expansive, catalytic role to unify and strengthen the cohesion of the clan members. The Han Army rite performed at Wula cements the blood ties passed down through the centuries and serves as a medium to settle conflicts among members, renews ties of family communication, and unifies family emotions. This is why the symbolic rite is still popular in Wula. The clan culture and tradition there will endure indefinitely as a result of the Han Army rite.

Ritual symbols that govern the Wula rite in Jilin province share a commonness with sacrificial rites in other parts of the region, and the author's research confirms this. The ceremonies and the ritual symbols of the Wula rite are similar to those used in the rites in Xinbin in the neighboring Liaoning province. Nonetheless, the rites of different groups in the region also have significant differences. The Wula rite maintains hereditary, family-based beliefs in that it focuses worship on ancestral gods, while the Xinbin rite is more an expression of regional rather than family beliefs.

Ancestor worship constitutes a core element of the Wula Han Army rite and is a key link in sustaining clan cohesion. A group needs enhanced unity in a way that has been accepted by all the clansmen since the early days, and ancestor worship fulfils that need. It meets the expectations of clan psychology for collective awareness. More specifically, the clan genealogy not only reinforces the sense of blood ties of clan members; it also gives them mental support in terms of a sense of belonging, so 
that harmony can be achieved among individuals and cohesion can be strengthened. In this lies the most important significance of the shamanistic ritual of the Han Army.

As has been rightly said, "In the ancient world when politics and religion were closely related, sacrifice was a crucial means of politics as well as an important aspect of education" (Yi 1987, p. 435). In shamanic clan rites, the shaman teaches the clansmen by telling the tales of their clan's origin, rise, and fall, and he cultivates respect for the ancestors by describing their feats and recounting heroic myths. Clansmen are taught respect for the elderly and care for the young in the Han Army rite, and children are taught to show reverence for ancestors by singing the shaman chant called "Shicengen (十层恩,Ten kindnesses), ${ }^{\prime 27}$ which advocates filial piety: How can an emperor govern his country in peace without fulfilling piety to his parents?

A white ape steals peaches to serve his mother; a lamb kneels down before drinking its mother's milk; a calf in the street cries for his mom. Even animals know how to serve their parents, and so, too, with human beings.

Your mother gave birth to you after a ten-month pregnancy. Upon seeing you when you came into the world, she smiled and has devoted herself to your life.

Alas, one kindness, two kindnesses, even ten kindnesses that you give back to your parents can never repay what they have done for you.

For its part, the procedure of the ritual of emptying the jade vases stresses family duty from a different perspective. The accompanying chant says,

Is there a quarrel between father and son, or between you and your brothers? Quarrel or argue, it doesn't matter. I will smooth your conflicts under the witness of the gods. From now on, you shall live happily together.

Father and son are joined by blood, and brothers are joined like a person's hand and foot.

Blood relationship overshadows any personal difference. From now on, you shall respect each other.

The symbolic ritual procedures and the accompanying chants help dispel conflict and foster a sense of brotherhood. The clan's shamanic belief that "filial piety is the first of all good" has a profound relation to Confucian mores.

\section{Conclusions}

Shamanic sacrificial ritual regularly enlightens and nurtures generation after generation, while satisfying people's religious, poetic, and moral needs. At the same time, it serves universal functions of mediating with the gods and spirits, preserving the identity of ethnic groups, and giving expression to human concepts and emotions in a satisfying manner. Overall, the unique symbolic system of the Han Army rite reflects common aspects of shamanic culture and, on the academic level, symbolic anthropology. It reflects, however, specific moral and cultural traits of the Han Army ethnic group and it highlights the assimilation that can take place among multi-religious cultures in the cultural integration of the Manchu and Han peoples that finds expression in it. With its strong regional color, the shamanic sacrificial rite of descendants of the Han Army as performed at Wula, in Jilin Province, preserves the traditional cultural orientation that has a great influence on the clan as a whole and on individuals within the clan. In this lies the wondrous rite's vitality.

Funding: This research received no external funding.

Conflicts of Interest: The author declares no conflict of interest.

27 Ten Kindnesses: Han Army chant advocating filial duty to parents. 


\section{References}

Crossley, Pamela Kyle. 1989. The Qianlong retrospect on the Chinese-matial (hanjun) banners. Late Imperial China 10: 63-107. [CrossRef]

Geertz, Clifford. 1973. The Interpretation of Cultures. New York: Basic Books.

Jilek, Wolfgang G. 1992. The Renaissance of Shamanic Dances in Indian Populations of North America. Diogenes 40: 87-100. [CrossRef]

Kister, Daniel. 2010. Shamanic Worlds of Korea and Northeast Asia. Seoul: Jimoondang.

Müller, Friedrich Max. 1909. Comparative Mythology: An Essay. London: George Routledge and Sons, Limited.

Peng, Zhaorong 彭兆荣. 2007. Renleixue lilun yu shijian 人类学理论与实践 [Theory and Practice of Anthropology]. Beijing: Minzu chubanshe 民族出版社.

Randall, John Herman. 1958. The Role of Knowledge in Westernnn Religion. Boston: Beacon Press.

Ren, Guangwei 任光伟, and Ying Sun 孙英. 1998. Dongbei hanjunqixiang de kaocha yu yanjiu 东北汉军旗香的考察与 研究 [Research on Rituals of the Northeast Han Army]. Taipei: Taipei shihezheng minsu wenhua jijinhui 台北施 和郑民俗文化基金会.

Sun, Jing 孙静. 2006. Shilun baqi hanjun yu manzhou de chayixing 试论八旗汉军与满洲的差异性 [Differences between the Han Armies and Manchu in the Eight-Banner of the Qing Dynasty]. Zhongyang minzu daxue xuebao 中央民族大学学报 5: 51-57.

Turner, Victor. 1967. The Forest of Symbols: Aspects of Ndembu Ritual. Ithaca and London: Cornell University Press. Wang, Zhonghan 王钟翰. 1990. Qingdai baqi zhong de manhan minzu chengfen wenti 清代八旗中的满汉民族成 分问题 [The Composition of the Manchu and Han Peoples of Eghit Banners of the Qing Dynasty]. Minzu Yanjiu 民族研究 3: 36-46.

Yi, Xuezhong 易学钟. 1987. Jinning shizhai shi'ermuchubeiqi shang renwu qundiao kaoshi 晋宁石寨12墓咜贝器 上人物群雕考释 [Research on the Group Carving on Shell-Containers Unearthed from Tomb No. 12, Shizhai, Jinning]. Kaogu xuebao 考古学报 4: 413-36.

(C) 2019 by the author. Licensee MDPI, Basel, Switzerland. This article is an open access article distributed under the terms and conditions of the Creative Commons Attribution (CC BY) license (http:// creativecommons.org/licenses/by/4.0/). 